Affect and the Role of Corporate Customer Expertise within Legal Services

\author{
Tony Garry* \\ De Montfort University \\ Contact Address \\ Department of Marketing \\ Leicester Business School \\ De Montfort University \\ The Gateway \\ Leicester LE1 9BH \\ Tel: 01162577226 \\ Fax: 01162506136 \\ Email: tgmar@dmu.ac.uk
}

Paper Submitted the Journal of Services Marketing

\footnotetext{
* The author wishes to thank Christine Ennew and Sally McKechnie of the University of Nottingham for their advice and support during the course of this research and to the helpful and insightful comments of the two anonymous reviewers on previous drafts of this paper.
} 


\section{Affect and the Role of Corporate Customer Expertise within Legal Services}

Purpose: To explore the role of Affect evoked among customers of differing expertise within a business-to-business credence service context and examine how this affects overall satisfaction judgments.

Methodology/Approach: Drawing on the Affect and Satisfaction literature, the paper examines affective reactions to service delivery within multi-national and regional corporate legal services markets. A two-stage methodology is adopted incorporating explorative interviews and a survey comprising of 252 users of corporate legal services.

Findings: Findings suggests the customer's ability to form expectation and performance assessments about the core service may have a moderating influence on affective reactions within a business-to-business credence service context. Customers of differing expertise will vary in the way they set service expectations and evaluate service delivery in relation to the technical, functional and affective components.

Practical implications: Organisations should devote effort to devising appropriate service delivery processes that are pertinent to the individual customer. This in turn has implications for the recruitment, training and empowerment of employees in credence services which have traditionally focused on technical qualifications and experiential knowledge as the key drivers of HRM strategies such as recruitment and reward systems.

Originality/value: Contributes towards an understanding of the role of customer expertise on Affect evoked within business-to-business credence services

Paper type: Research Paper

Key words: Affect, customer expertise, credence services 


\section{Introduction}

Despite its long history in general psychology, Affect and more specifically emotion, is a relatively new topic in the marketing arena. However, there is increasing evidence to suggest the existence of an empirical link between Affect and satisfaction (Barnes and Howlett, 1998). Indeed, many researchers question the reliability of previous studies that have ignored the emotional component of satisfaction (Liljander and Strandvik, 1997).

However, previous research in this area has assumed that customers are homogenous (e.g. Smith and Bolton, 2002) and largely ignores the concept of 'customer expertise'. Consequently, this paper reports on a study which aims to:

- Explore the effect of emotions generated on customer satisfaction within a businessto-business service context

- Examine how this may vary according to the expertise of the customer and their ability to form expectation and performance assessments about the 'functional' and 'technical' attributes of the service (Grönroos, 1984).

The paper is structured as follows. First, there is a brief synopsis of the recent literature on emotion and consumption satisfaction and research propositions are developed consistent with the research aims. The research design is then described and the results discussed. The paper concludes with managerial implications and recommendations for future research. 


\section{Literature Review}

Research in this field provides evidence to suggest the existence of an affective dimension to service delivery which stresses the importance "of how customers are made to feel in their dealings with their provider" (Barnes and Howlett, 1998: p. 21). To fully understand how emotion relates to satisfaction, it is necessary to review the literature involving measures of both so that the relationship between them can be assessed.

Early studies by Westbrook (1987) and Oliver (1993) in this field demonstrated;

- that positive and negative Affect represented relatively independent dimensions of affective response to products (Westbrook, 1987)

- that positive and negative Affect were not mutually exclusive (Westbrook, 1987)

- that reports of positive and negative Affect related directly to product satisfaction judgments (Westbrook, 1987)

- that product attribute satisfactions and dissatisfactions were the source of Affect (Oliver, 1993) and;

- Affect may partially mediate the attribution influences on overall satisfaction (Oliver, 1993)

However, these research findings are primarily in tangible, product based contexts. When placed in a service context, they may have deficiencies. More specifically, where there is a high degree of interaction with a service provider, the service provider may become the focal point of the service encounter (Bitner, 1990). Secondly, there is an assumption that 
the customer has the ability to form expectation and performance assessments about the attributes of the core or technical product (Alford and Sherrell, 1996).

Credence services do not always provide opportunities for these assessments to take place. In such circumstances, other aspects of the service may take on a higher degree of significance (e.g. Crosby and Stephens, 1987). In an attempt to address these deficiencies, Alford and Sherrell (1996) investigated the role of Affect in evaluating satisfaction within a credence service context. Their results suggest that customers will partly use their affective reaction to the service provider when evaluating overall satisfaction.

However, previous research in this field has assumed that customers are homogeneous (e.g. Smith and Bolton, 2002). More specifically, it assumes customers are either qualified or have experiential expertise and are therefore in a position to gauge the attributes of the service or product (e.g. Oliver, 1993) or, as typically associated with credence service markets, they are not (e.g. Alford and Sherrell, 1996). There is however, increasing evidence to suggest that customers within certain credence contexts are heterogeneous. In such cases, customers may possess the ability to form expectation and performance assessments about the service they are receiving and they may have pertinent technical qualifications, skills, knowledge and experience that enable them to do so (e.g. Hanlon, 1997). 


\section{Development of Propositions}

The purpose of the current research is to examine the roles of the affective, technical and functional components of service provision, the nature of their evaluation and how the level of customer expertise may moderate these within a business-to-business credence service context. More specifically, the following propositions are suggested;

Proposition 1: Where there is a higher level of customer expertise, there will be a higher reliance on evaluation of the technical attributes of the service rather than the affective or functional attributes when deriving overall satisfaction judgments.

Proposition 2: Where there is a lower level of customer expertise, there will be a higher reliance on evaluation of the functional and affective attributes of the service rather than the technical attributes when deriving overall satisfaction judgments.

\section{Methodology}

In order to investigate these propositions, a two-stage methodology was adopted incorporating exploratory interviews and a survey.

Stage One: Exploratory interviews

Initially, fourteen exploratory interviews were conducted within the context of multinational and regional corporate legal services. A purposive sampling approach was used to recruit interviewees and ensure an appropriate spread of customer expertise. Care was 
taken to identify an appropriate cross-section of lawyers and customers. On the demand side, five interviews were conducted with individuals involved in the selection and evaluation of legal services used by their organisations. The interviewees consisted of inhouse lawyers working for large multi-national, blue chip or public sector organisations and owner-managers of small and medium sized enterprises (SMEs). This ensured an appropriate spread of customer expertise ( see Appendix 1). On the supply side, interviewees consisted of nine practice lawyers working for a range of regional and national law firms who were engaged in the provision of corporate and commercial advice to organisational clients (see Appendix 2).

Each interview lasted around 20-30 minutes. The interviews were taped and subsequently transcribed onto hard copy to facilitate analysis. The transcripts were coded and analysed for content and common themes and patterns were identified across and between cases. Three key findings relevant to this research emerged as a result of the analysis;

$\bigcirc$ that service satisfaction comprises of a cognitive and affective component

$\circ$ that there are varying degrees of customer expertise

o that the role accorded to the cognitive and affective components of the service may vary according to the degree of customer expertise

These findings are now examined in more depth. Firstly, the findings substantiated the existence of a cognitive and affective component of the service. The cognitive component comprises of technically based attributes (e.g. quality and commerciality of legal advice) and functional based attributes (e.g. accessibility, promptness etc). At a general 
level, the existence of positive and negative Affect was also identified. Primary among these were blended emotions such as like/dislike (e.g. Bagozzi, 1992). For example, Client B states: "I think you can still instruct solicitors without getting on with them. It is like being..... 'I don't have to like them I just have to work with them ".

More specifically, lower level positive and negative emotional reactions were also identified or alluded to. Low level negative reactions included 'annoyance' (e.g. Weiner et al. , 1979) and 'frustration' (e.g. Roseman, 1991). For example, Solicitor C states: "There are clients ......who will ask for your advice and ignore it and then we go around in circles". Contempt was also alluded to (e.g. Plutchik, 1980) as Solicitor H illustrates: "I can think of some clients that you know are going to be awkward and they just sort of go out their way to be awkward but they're quite happy to stay on with you but be as rude as anything”. Low level positive emotional reactions included 'contentedness' (e.g. Watson and Tellegen, 1985) , 'comfort' (e.g. Watson and Tellegen, 1985), 'enjoyment' (e.g. Roseman, 1991) and 'caring' (e.g. Bagozzi, 1992). For example, Solicitor C suggests: “.... as long as clients are comfortable with what we do, we are quite content with a much more informal and friendly approach".

Secondly, the results suggest that professional services may also be consumed by qualified professionals and that there are differing degrees of technical qualifications, skills, knowledge and experience that customer organisations may possess within the narrow and well-defined body of legal expertise. The implication of this is that there are varying degrees of customer expertise in terms of: 
- their ability to issue instructions to solicitors acting on their behalf

$\circ$ to understand the features and benefits of the service they are receiving

- their ability to gauge the technical attributes of the service delivered related to these.

One solicitor very succinctly illustrates some of the differences that exist related to customer expertise and the implications that these may have in terms of the service delivery and the nature of solicitor-customer interaction:

"They [in-house lawyer clients] will have a pretty good idea as to what the cost of the service is in the market place. They will also have a pretty good idea of what the expertise is of the law firms they might want to use. That is a very different situation if, for example, you have a chap who's built up a business which is his sole asset and he's thinking of retiring and he wants to sell. He needs to have confidence in the relationship."

Solicitor B

Finally, the results appear to demonstrate that where performance assessments about service attributes are difficult, the role of the affective component may become more prominent. For example, solicitor D states: “....with the owner-manager clients, it is in terms of relationships... you know, personal relationships" and solicitor E states: "If you have a less sophisticated client, the personal relationships may override anything else....as in the competition in the market". The findings also suggest performance evaluation of the overall service may take place after affective judgments are have been made. To quote Solicitor D again: "[the owner manager] will go around the lawyers that are available until he finds a person he likes and feels comfortable with" and Solicitor I 
states: "They [the client organisation] indicate that there's certain people they'll deal with, certain people they won't. So part of it must be simply the ability of the client...individuals to get on and like each other".

\section{Stage two: Survey}

Given the results of the exploratory research interviews, further investigation was deemed appropriate in order to develop the research. Cross sectional data was collected relating to organisational customer perceptions of their ongoing satisfaction levels with their law firms. The next section describes the methodology and findings related to this stage of the research.

\section{Questionnaire Design}

The questionnaire comprised five sections. The first section consisted of questions designed to collect factual information relating to the number and size of law firms used by respondents and the reasons for this (see Appendix 3). The second section of the questionnaire contained a number of scale items used to measure satisfaction relating to the cognitive element of the service. This was measured using a 7 point Likert scale and asked respondents to 'indicate to what extent you are satisfied with the ongoing quality of service you receive from your main firm of solicitors" (1= "Not at all satisfied" and 7= "Extremely satisfied"). These were based on Hart and Hogg's (1998) service evaluation criteria scale developed for corporate legal services (see Appendix 4). 
The third section of the questionnaire contained a number of scale items related to the emotional component of the service (see Appendix 5). This was measured using a 7 point Likert scale and asked respondents to 'indicate to what extent you feel the following emotions when considering your ongoing relationship with your main firm of solicitors' (1= "Not at all" and 7= "Extremely"). This was based on Richins (1997) Consumption Emotions Set (CES).

The fourth section of the questionnaire contained a number of scale items related to the importance respondents attached to the components of service delivery. These were drawn from dimensions previously identified as a result of a review of the relevant literature and the results of the exploratory interviews and consisted of: the quality of the legal advice; interaction with the solicitor; the responsiveness of the solicitor; getting on at a personal level and the fees charged for the advice given (see Appendix 6). This was measured using a 7 point Likert scale and asked respondents 'how important do you consider the following criteria when assessing the quality of service you receive from your main firm of solicitors?' (1= "Not at all important" and 7= "Extremely Important").

The fifth section of the questionnaire consisted of questions designed to assess respondents' expertise in relation to their knowledge of law and legal services. This included a section of scale items related to a self report of respondents' expertise based on Mitchell and Dacin's (1996) assessment of customer expertise criteria scale (see Appendix 7). Along with these self report measures, respondents were also asked about 
the nature of their educational background and more specifically, whether they possessed a legal qualification and at what level.

Overall satisfaction was measured using a single item 7 point Likert scale (e.g. Cronin and Taylor, 1992; Odekerken-Schroder et al., 2000) which asked respondents to indicate the extent to which they currently agreed or disagreed with the following statement 'In general, we are completely satisfied with our main firm of solicitors' (1= "Strongly Disagree" and 7= "Strongly Agree").

The questionnaire was extensively pre-tested. This was done by administering the questionnaire to three sets of respondents (see Appendix 8). The first set comprised of solicitors working for practices engaged in providing legal services to business organisations. The second set comprised of individuals engaged in the selection and assessment of law firms for their organisations and included customers with and without relevant legal expertise. The third set comprised of 'academics knowledgeable in the field' (Bagozzi, 1994). Each question was individually examined and scrutinised by the pilot respondent in the presence of the author. The feedback provided was incorporated into the questionnaire and the following amendments were made:

- the use of the phrase 'personal chemistry' was interpreted as having sexual connotations and therefore deemed inappropriate and was replaced with 'how well you get on with your solicitor on a personal basis.'

- 'Reassurance and Confidence' was interpreted as not being mutually exclusive insofar as advice may be given confidently to a customer but it may not be very 
reassuring for the customer in terms of the content. This question was therefore replaced with two individual questions.

- the addition of the question 'The law firm's cultural fit with your organisation's style of doing business' as this was viewed as a significant factor to some organisations in determining the recruitment and retention of law firms.

- the rewording of the question 'the knowledge of the partner giving the advice' to 'the legal specialisation of the solicitor giving the advice' to reflect the choice criteria more accurately used.

\section{Data Collection}

To appropriately investigate the research propositions, it was imperative that the population to be surveyed should encompass both customers with and without relevant legal expertise and that critically, these sub-samples could be identified and labelled accurately. To ensure this, different sampling techniques were adopted for each subsample.

The first sample set comprised of a convenience sample of 460 in-house lawyers working for large national or multi-national organisations. These were taken from The Legal 500 Directory. This publication profiles the major law firms in the UK but also comprises a section on lawyers working 'in-house' for commercial or non-profit making organisations. This information was used to target directly and personally those individuals most likely to be involved in the selection and assessment of legal services 
provided by law firms and who were in a position to form expectation and performance assessments about the service (i.e. customers with a high level of expertise).

The second sample set comprised of 460 Managing Directors/Owner-managers of small and medium sized enterprises (SMEs). The sampling frame consisted of 4,127 SMEs from the Midlands region of the UK. These were taken from the FAME database. As there was no previously published research available to indicate who is involved in the selection and assessment of legal services within such organisations, reliance was placed on the results of the exploratory interviews, which suggested that these were the roles most likely to be involved. It was also anticipated, in contrast to the other sample set, that these sampling units would not be in a position to form expectation and performance assessments about the service and were therefore appropriate for customers without the relevant legal expertise. The Midlands region was selected as it was anticipated that the geographical vicinity of the University may illicit a higher response level. Checks were made to ensure that the Midlands business profile was similar to the national profile and there were, therefore, no major issues of representativeness.

A total of 920 questionnaires were mailed with personalised cover letters and a pre-paid return envelope. A follow up letter together with another copy of the questionnaire and another pre-paid envelope was mailed out three weeks later. There were a total of 255 returned usable questionnaires. A further eighteen questionnaires were returned unanswered or were largely incomplete and these were discarded from further analysis. The response rate for in-house lawyers was $33.7 \%$ and for SME respondents was $22.2 \%$. 
This overall response rate of $27.7 \%$ is not uncommon for postal surveys and was considered to be satisfactory given that other studies focusing within business-to-business markets report response rates lower than 5 percent (e.g. Morgan and Hunt, 1994).

\section{Key Findings}

\section{Reliability and Validity}

Before performing the actual analysis it was necessary to check whether a non-response bias could threaten the quality of the data. Time extrapolation tests (Armstrong and Overton, 1977) were conducted using independent sample t-tests to compare the mean scores of the initial respondents and those responding to the follow up letter. These tests revealed that none of the items used showed a significant difference between early and late respondents therefore providing evidence for the absence of non-response bias.

Further independent sample t-tests were conducted to evaluate the respondents self assessment in relation to their knowledge of law and legal services. The reliability of Mitchell and Dacin's (1996) scale was checked using Cronbach's alpha. This achieved an alpha score of .92 which is above .7 so the scales can be considered reliable with this sample. As anticipated, the independent sample t-test results showed there were statistically significant differences $(p=<.05)$ in the expected direction between the group means on questions relating to the respondents familiarity with legal services, confidence about which characteristics of the legal service are important, classification of their legal knowledge and whether they considered they knew a lot about the law. These results were collaborated by the data collected on the respondents' educational qualifications. Of 
the in-house lawyer respondents, $100 \%$ had a minimum of a degree level qualification in law (LLB) with $66 \%$ having an LLM or a post-graduate professional qualification in law such as the Legal Practice Certificate (LPC) or its equivalent. This contrasted with the respondents from SMEs where $52 \%$ of the respondents had a degree or post-graduate qualification but none were related to law.

Given these results, it would seem appropriate to assume that one set of respondents have a higher degree of expertise than the other in terms of their ability to issue advice and instructions to the service provider, to understand the features and benefits of the service they are receiving and crucially, in terms of their ability to gauge the technical attributes of the service.

Subsequently, factor analysis was conducted on the affective and cognitive components. An 'a priori' approach was adopted (Hair et al., 1995; Stewart , 2001) whereby the number of factors specified was based on the empirical research findings resulting from the exploratory interviews and the Affect/satisfaction literature .

\section{The Affective Component}

Initially, the suitability of the data for factor analysis was assessed. Inspection of the correlation matrix revealed the presence of a large number of coefficients of .3 and above. The Kaiser-Meyer-Olkin (KMO) value was .872 exceeding the recommended value of .6 (Kaiser, 1970) and the Bartlett's Test of Sphericity (Bartlett, 1954) reached statistical significance, supporting the factorability of the correlation matrix. Subsequent 
to completing these tests, the affective component was subjected to a principal component factor analysis.

The loading of these items was as anticipated. The two-factor solution accounted for $56.88 \%$ of the variance. All the items loaded significantly (minimum of .55 for a sample of this size according to Hair et al., 1995) with the exception of 'relief' and this item was removed from further analysis. With three of the items ('discontentment', 'frustration' and 'calmness') there was some cross loading but as their values were less than the 0.55 cut off they were not seen as problematic. The results are presented in Table I below.

\section{-INSERT TABLE I HERE-}

As anticipated, the results confirm the existence of positive and negative affective elements to the service with the first factor being characterised by negative emotions (29.56\% of variance) and the second factor being characterised by positive emotions (27.32\% of variance).

\section{Cognitive Component}

The cognitive component of the service encounter was also subjected to a principal component factor analysis with a varimax rotation. Once again, prior to performing the analysis, the suitability of the data for factor analysis was assessed. Inspection of the correlation matrix revealed the presence of many coefficients of .3 and above. The Kaiser-Meyer-Olkin value was .963 and the Bartlett's Test of Sphericity (Bartlett, 1954) 
reached statistical significance. As previously, an 'a priori' approach was adopted (Hair et al., 1992). Satisfaction with 'fees charged for the advice given' and overall satisfaction were excluded from the analysis as they were both single scale items.

The loading of these items was as anticipated. The three-factor solution accounted for $65.1 \%$ of the variance. All the items loaded significantly with the exceptions of the frequency of contact iniated by the solicitor', 'the degree of partner involvement' and 'the degree of attention the solicitor gives your request'. These were removed from subsequent analysis. With two items there was significant cross loading. 'The degree of confidence with which the advice is given' may be ambiguous insofar as it may be interpreted from a personal, interaction perspective or technical perspective. Likewise, 'the degree of reassurance with which the advice is given' may be ambiguous insofar as the legal advice, whilst being correct, may not be reassuring from a customer perspective if it is contrary to their desired outcome. These items were also removed from subsequent analysis. The results are presented in Table II below. 
The results confirm that the cognitive component may not only comprise of a 'technical component' (26.8\% of variance) but also an 'interaction component' $(19.6 \%$ of the variance) and a 'responsiveness component' (18.7\% of the variance).

\section{Reliability}

The reliability of all the scales was established by utilising Cronbach's alpha. The technical, interaction and responsiveness components had an alpha score of $.921, .848$ and .822 respectively. Negative Affect and positive Affect had alpha scores of .857 and .867 respectively. These values are all above .7 so the scales can be considered reliable with this sample.

\section{Predictors of satisfaction}

Reverse stepwise regression was conducted to identify the variables that are the most important in predicting satisfaction for the in-house lawyer and SME respondent groups respectively. To ensure there were no violations of assumptions about the data, appropriate tests were conducted. However, White's test (1980) for heteroscedasticity was significant for the in-house lawyer respondents suggesting that this assumption was being violated. For this reason the variables were transformed prior to regression analysis. The results of the regression for the two sets of respondents may be seen in table III and IV 
-INSERT TABLE III HERE-

For the SME respondents, sixty two percent $(62.1 \%)$ of the variance in overall satisfaction was explained by four variables. The cognitive element comprising of the responsiveness component $(\beta=.332, p=.000)$, the interaction component $(\beta=.304$, $p=.002)$, the negative affective component $(\beta=.-.246, p=.000)$ and the positive affective component $(\beta=.198, p=.007)$. Thus, the technical component and fees are not significant for this group.

-INSERT TABLE IV HERE-

For the in-house lawyer respondents, sixty six percent $(66.1 \%)$ of the variance in overall satisfaction was explained by five variables. These comprised of the technical component $(\beta=.259, p=.003)$, fees $(\beta=.231, p=.001)$, the interaction component $(\beta=.202, p=.015)$, the responsiveness component $(\beta=.170, p=.012)$ and positive Affect $(\beta=.142, p=.016)$. Negative Affect was not significant for this group of respondents. 


\section{Discussion}

Proposition 1 appears to be substantiated. The quality of the technical component makes the most significant contribution to overall satisfaction for the in-house lawyer respondents. This is collaborated by the importance attributed to this component in terms of the overall service delivery offering $(\bar{x}=6.5, s=.57)$. The fees charged also make a significant contribution to overall satisfaction for this group. This would appear to substantiate the research of Hart and Hogg (1998) when they describe the procurement of legal services by such individuals as being 'like any other commodity' (p.58).

There is further evidence for this when considering the number of law firms retained by in-house lawyer respondents and the rationale provided for this. Over $80 \%$ used four or more law firms with legal specialisation being the most cited reason. Other reasons cited included:

- $\quad$ ensuring checks and balances between the law firms that supplied legal advice were maintained by making direct comparisons of fees charged and quality of advice provided,

- provincial firms being cheaper for less complex advice than multi-national London based 'City' firms

- risk management (avoidance of over reliance on one law firm)

Proposition 2 also appears to be substantiated. For the SME respondents, it is likely that the technical component is not significant because of the difficulty such respondents have in gauging its quality. When respondents are asked 'How confident are you about which 
elements of a legal service are important?', over 50\% responded they were unconfident or neutral and only $35.3 \%$ stated they were slightly confident.

The exploratory interviews conducted with this group suggest that the quality of the technical component is perceived as a hygiene factor and is implicit within the service offering. This perception emanates from a number of sources. These include:

- Confidence in the extended academic preparation of the professional which ensures they possess the pertinent technical skills.

- The existence of a formal professional body which set levels of competence and standards for its members and enforces codes of ethics where appropriate (i.e. The Law Society).

- The intuitive logic of the customer and the experiential consistency with which the service process is performed (Alford and Sherrell, 1998).

As a result, a higher reliance is placed on the functional attributes of the service delivery, particularly the more cognitively measurable of these such as promptness and accessibility. However, satisfaction generalisations are also being made on the 'softer' components of the service delivery such as affective reactions and solicitor-customer interactions.

One interesting result to emerge was that for SME respondents, positive and negative Affect contributed to overall satisfaction/dissatisfaction but for in-house solicitors only positive Affect increased satisfaction. A possible explanation for this may be the 
'atmosphere' (IMP Group, 1982) within which the interaction of these individuals traditionally takes place. Much interaction between solicitors within a professional context is, by its nature, confrontational. Thus, negative Affect is not significant in decreasing satisfaction. However, when interaction is constructive than positive Affect evoked may increase overall satisfaction.

\section{Managerial Implications}

The managerial implications for law firms of this research may be classified into four key areas:

- engendering and embedding a higher degree of client focus

- devising appropriate service delivery offerings relevant to individual client needs

- developing employee sensitivity to emotional evocation and its consequences

- incorporating an emotions component into their existing satisfaction measurements

Engendering and embedding a higher degree of client focus

Much of the work on the nature of professionals has examined the ability they have to interpret and transform customer difficulties into some form of technical solution and this approach is still prevalent within many law firms. Within a business-to-business legal context, research suggests a proportion of law firms still do not appear to be driven by client needs and '.....marketing continues to be viewed as a shoddy endeavour' (Harris 
and O’Malley, 2000:p. 65). Consensus suggests such firms wish to retain at least some elements of the older form of professionalism in terms of providing legal advice which focuses on technical excellence. These firms are, in the main, hostile to the 'managerialist values of the commercialised professional' (Hanlon, 1997: p. 821). This research suggests this traditional archetype of the professional partnership firm needs to incorporate and engender a stronger commercial/entrepreneurial element into their culture which culminates in an increased effort to focus on understanding the business and commercial issues facing their clients. Such firms need to re-organise their structures and redefine their perception of professionalism to embrace a value system which emphasises optimising value added provision for clients.

Consistent with these changes are the adaptation of Human Resource practices and rewards. Historically, the 'up or out' (Malos and Campon, 1995) career progression model and profit sharing between equity partners (Morris and Pinnington, 1998) needs to adapt so as to incorporate more client focused reward systems. Potential partners within law firms should be assessed on their ability to increase the firm's business through developing ongoing and stable relationships with clients rather than purely on specified fee earning and financial targets. Such relationships are recognised by many as being mutually beneficial and powerful enablers within the legal profession at both a professional and personal level. To quote Harris et al. (2003), 'These relationships facilitate goal achievement, provide access to important social and professional networks and enhance long-term career opportunities' (p. 29). 
Devising appropriate service delivery offerings relevant to individual client needs

Law firms need to devote effort to identifying and devising appropriate service delivery offerings that are relevant to their individual client needs and endeavour to ascertain where the prioritisation of the relational components may lie. This should, in part determine "what kind of relationship is sought and in what circumstances" (Blois, 1996) so that law firms can attempt to manage the service delivery and the evolving relationship with individual clients appropriately. This research demonstrates that customer expertise will be a determinant factor as to how service expectations are set and evaluations of service delivery are made. Understanding the business and commercial issues facing their clients may only be one consideration in building strong relationships. It is clear from this research that emotional intelligence and sensitivity may be as pertinent as technical and commercial prowess in ensuring the success of such relationships. Law firms should focus on these 'softer' attributes to a greater extent when considering relationships with their clients. Indeed, the concept and consequences of customer-employee 'rapport' (Hennig-Thurau et al., 2006) is increasingly being recognised in terms of its influence on relational interactions. It is possible that more successful professional service organisations will be able to identify the social and emotional requirements of their clients and respond accordingly. This research suggests that allocation of client relationship managers by law firms should not be based purely on legal specialism but also consider social compatibility and the development of client-solicitor 'rapport'. 
Developing employee sensitivity to emotional evocation and its consequences

Barsade (2002) highlights the importance of emotional contagion and how 'catching another person's emotions' [p. 644] may affect the dynamics of interaction. Crucially, Grandey (2003) makes a clear distinction between 'shallow acting' whereby employees change 'only their outward behaviour...... and may simply put on a smile and pretend to be cheerful and friendly' [p.59] and 'deep acting' whereby employees' project anticipated emotions by attempting to create these internally through self induction. Hennig-Thurau et al. (2006) are able to demonstrate how anticipated and authentic displays of emotions by employees may evoke customer Affect. This study augments these findings by demonstrating the link between Affect evoked through interaction and its impact on overall satisfaction judgments. Thus, law firms and their employees need to be aware and sensitive to the issue that the transfer of positive emotions from employees to clients through sincere and authentic emotional contagion may influence overall customer satisfaction levels. This may require additional training that teaches the processes of deep acting such as perspective-taking techniques.

Finally, law firms endeavouring to assess their clients' satisfaction should consider incorporating an emotions component into their existing satisfaction measurement strategies.

\section{Further Research}

Affect, by nature, is a nebulous dimension. It is the subjective appraisal of the evoking stimulus in the context of the individual's needs and coping potential that determine 
emotions evoked and not the characteristics of the event or stimulus itself (Nyer, 1997). Thus, the individual's unique emotional response to the stimulus determines their subsequent coping mechanism. This has implications for marketers because some of the coping mechanisms commonly used by customers include complaint behaviour, word of mouth recommendation, repurchase intention and relationship continuation or termination. Thus, this conceptually rich and individually unique dimension requires further investigation at a more in-depth level. Qualitative research focusing on individual episodes of interaction between the parties to the relationship may be appropriate in examining the antecedents of particular emotions evoked, the nature of the appraisal of the evoking stimulus and the subsequent coping mechanisms that culminate from this. 


\section{References}

Alford, B. and Sherrell, D., (1996), "The Role of Affect in Consumer Satisfaction Judgments of Credence-Based Services”, Journal of Business Research, Vol. 37, pp71-84

Armstrong, J. and Overton, T., (1977), "Estimating Non Response Error in Mail Surveys", Journal of Marketing Research (14), August, pp. 396-402

Bagozzi, R.P., (1992) "The Self Regulation of Attitudes, Intentions and Behaviour”, Social Psychology Quarterly, 55, pp 178-204.

Bagozzi, R., (1994), Advanced Methods of Marketing Research, Blackwell Business, Cambridge, Massachusetts

Barnes, J. and Howlett, D., (1998), "Predictors of Equity in Relationships between Financial Service Providers and Retail Customer", International Journal of Bank Marketing, Vol. 16, No. 1, pp15-23.

Barsade, S., (2002), “The Ripple Effect: Emotional Contagion and Its Influence on Group Behaviour”, Administrative Science Quarterly, No. 47, pp. 644-75

Bitner, M., J., (1990), "Evaluating Service Encounters: The Effects of Physical Surroundings and Employee Responses", Journal of Marketing, No. 54, April, pp. 69 82 .

Blois, K. J. (1996), "Relationship Marketing in Organisational Markets: When is it Appropriate?” Journal of Marketing Management, No. 12, pp. 161 - 173.

Cronin, J. and Taylor, S., (1992), "Measuring Service Quality: A Re-examination and Extension" Journal of Marketing Management, Vol. 56, July, pp. 55 - 68

Crosby, L.A. and Stephens, N., (1987), "Effects of Relationship Marketing on Relationship Satisfaction, Retention and Prices in the Life Insurance Industry", Journal of Marketing Research, Vol. 24, November, pp. 404 - 411.

Grandey, A., (2003), “When "The Show Must Go On”: Surface and Deep Acting as Determinants of Emotional Exhaustion and Peer Rated Service Delivery", Academy of Management Journal, No. 46, pp. 86-96

Grönroos, C., (1984), Strategic Management and Marketing in the Service Sector, London, Chartwell-Bratt 
Hair, J., Anderson, R., Tatham, R. and Black, W. (1995), Multivariate Data Analysis, Maxwell MacMillan International

Hanlon, G., (1997), " A Profession in Transition? - Lawyers, The Market and Significant Others", The Modern Law Review, November, Vol. 60, no. 6, pp. 798-822

Harris, L. \& O'Malley, L. (2000), "Maintaining Relationships: A Study of the Legal Industry":, .The Service Industries Journal, No. 20(4), pp. 62-84.

Harris, L. O'Malley, L. \& Patterson, M. (2003), "Professional Interaction: Exploring the Concept of Attraction". Marketing Theory, No. 3(1): pp. 9-36.

Hart, S. and Hogg G., (1998), "Relationship Marketing in Corporate Legal Services" The Service Industries Journal, Vol. 18, No.3, pp. 55-69

Hennig-Thurau, T., Groth, M., Paul, M. and Gremler, D, (2006), “Are All Smiles Created Equal? How Emotional Contagion and Emotional Labor Affect Service Relationships", Journal of Marketing, Vol. 70, pp. 58-73

IMP Group (1982), “An Interaction Approach”, International Marketing and Purchasing of Industrial Goods, Wiley, Chichester, pp. 10-27 In: Ford, D. (Ed), (1990), Understanding Business Markets: Interaction, Relationships and Networks, Academic Press, London.

Liljander, V. and Strandvik, T. (1997), "Emotions in service satisfaction", International Journal of Service Industry Management, Vol. 8, No. 2, pp148-169

Malos, S. and Campion, M. (1995), "An Options-Based Model of Career Mobility in Professional Service Firms" Academy of Management Review, Vol. 20, No. 3, pp. 611645

Mano, H. and Oliver, R.L. (1993), "Assessing the Dimensionality and Structure as Consumption Experience: Evaluation, Feeling and Satisfaction", Journal of Consumer Research, 20: 451-466

Mitchell, A. and Dacin, P., (1996),"The Assessment of Alternative Measures of Consumers Expertise”, Journal of Consumer Research, Vol. 23, pp.219-239

Morris, T. and Pinnington, A., (1998), "Patterns of Profit Sharing in Professional Firms", British Journal of Management, Vol. 9, No. 1, pp. 23-39

Morgan, R.M. and Hunt, S.D., (1994), "The Commitment - Trust Theory of Relationship Marketing”, Journal of Marketing, Vol. 58, July, pp. 20 - 38, 
Nyer, .U; P. (1997), "A Study of the Relationships Between Cognitive Appraisals and Consumption Emotions", Journal of the Academy of Marketing Science, Vol. 25, No. 4, pp. 296-304

Oliver, R.L., (1993), "Cognitive, Affective and Attribute Basis of the Satisfaction Response", Journal of Consumer Research, 20, pp 418-430

O'Malley, L. and Harris, L. (1999), "The Dynamics of the Legal Market: An Interaction Perspective", European Journal of Marketing, Vol. 33, No. 9/10, pp. 874-895

Plutchik, R. (1980), Emotion: A Psychoevolutionary Synthesis. New York: Harper and Row.

Richins, M. (1997), "Measuring Emotions in the Consumption Experience", Journal of Consumer Research, Vol 24, pp 127-146.

Roseman, I. J. (1991), “Appraisal Determinants of Discrete Emotions” . Cognition and Emotion, Vol. 5: pp. 161-200.

Smith, A. and Bolton, R. (2002), “The Effect of Customers' Emotional Responses to Service Failures on their Recovery Effort Evaluation and Satisfaction Judgments", Journal of the Academy of Marketing Science, Vol. 30 No. 1, pp. 5-23

Stewart, D. , (2001), "Exploratory versus Confirmatory Factor Analysis", Journal of Consumer Psychology, Vol.10, No. 1\&2, pp.75-82

Watson \& Tellegen. (1985), "Towards a Consensual Structure of Mood",. Psychological Bulletin, No. 98,: pp.219-235.

Weiner, B. Russell, D. \& Lerman, D. (1979), "The Cognition-Emotion Process in Achievement-Related Contexts" . Journal of Personality and Social Psychology, 37(July): pp.1211-1220.

Westbrook, R.A. (1987), "Product/Consumption-Based Affective Responses and Postpurchase Processes", Journal of Marketing Research, 24, 258-270.

White, H. (1980), "A Heteroscedasticity Consistent Covariance Matrix Estimator and a Direct Test of Heteroscedasticity" Econmetrica, Vol. 48, pp. 817-838 
APPENDIX 1: DETAILS OF INTERVIEWEES ON THE DEMAND SIDE FOR CORPORATE LEGAL SERVICES

\begin{tabular}{|c|c|c|}
\hline$\underline{\text { Respondent Code }}$ & $\begin{array}{c}\frac{\text { Size of Organisation }}{\text { (No. of Employees) }} \\
\text { Client A (In-house Lawyer) }\end{array}$ & \begin{tabular}{c} 
Brief Description of Organisation \\
\hline Client B (In-house Lawyer)
\end{tabular} \\
\hline Client C (In-house Lawyer) & 2,181 & Global Merchant Bank \\
\hline Client D (Director) & 15,174 & International Cosmetics Company \\
\hline Client E (Director) & 4 & Regional County Council \\
\hline & 2 & Construction \\
\hline
\end{tabular}

\section{APPENDIX 2: DETAILS OF INTERVIEWEES ON THE SUPPLY SIDE FOR CORPORATE LEGAL SERVICES}

\begin{tabular}{|c|c|c|}
\hline Respondent Code & Position & $\frac{\text { Size of Law Firm }}{\text { (No. of Partners) }}$ \\
\hline Solicitor A & Partner & 27 \\
\hline Solicitor B & Partner & 41 \\
\hline Solicitor C & Solicitor & 65 \\
\hline Solicitor D & Partner & 104 \\
\hline Solicitor E & Partner & 33 \\
\hline Solicitor F & Partner & 194 \\
\hline Solicitor G & Partner & 8 \\
\hline Solicitor H & Partner & 289 \\
\hline Solicitor I & Associate Partner & \\
\hline
\end{tabular}




\section{APPENDIX 3: NUMBER AND SIZE OF LAW FIRMS USED BY RESPONDENTS AND THEIR METHODS OF INTERACTION}

- How many law firms does your organisation currently use? [one, two, three, four or more, don't know]

What is the size of your main law firm? (How many partners does it have?) [0-9, 10-25, 26-50, 5175, 76-100, 100+, don't'know)

- If your organisation is currently dealing with more than one firm of solicitors, what are the reasons for this? [open question]

- Which of the following methods do you prefer to use to communicate with your main firm of solicitors? [face to face, phone, letter, email, other]

- Do you have a main contact solicitor (Client Relationship Manager) at your main firm of Solicitors? [yes, know]

- On average, how often do you meet your main law firm's (contact) solicitor (s) per year?

- On a business basis [never, once or twice, three or four, five or six, seven or eight, nine to twelve, twelve+]

- On a social basis (e.g. corporate hospitality) basis [never, once or twice, three or four, five or six, seven or eight, nine to twelve, twelve+]

\section{APPENDIX 4 : SATISFACTION DIMENSIONS OF THE COGNITIVE COMPONENT OF THE SERVICE (BASED ON HART AND HOGG'S (1998) SERVICE EVALUATION CRITERIA FOR LEGAL SERVICES)}

To what extent are you satisfied with the ongoing quality of service you receive from your main firm of solicitors? [Seven point Likert scale: $1=$ "Not at all satisfied" and 7= "Extremely satisfied"]

- The degree of empathy shown by the solicitor when dealing with you

- The level of legal detail provided by the solicitor

- The courtesy of the solicitor

- The promptness of the advice given

- The degree of reassurance with which the advice is given

- The accessibility of the solicitor

- The law firm's cultural fit with your organisation's style of doing business

- The legal specialisation of the solicitor giving the advice (e.g. Employment law, patent law etc)

- The commercial viability of the legal advice

- The frequency of contact initiated by the solicitor

- The clarity of the advice given (The solicitor uses clear and understandable language)

- The reliability of the solicitor

- The degree of attention the solicitor appears to give your request

- The degree of partner involvement

- The quality of the legal advice given

- How well you get on with the solicitor on a personal basis

- The degree of confidence with which the advice is given

- The fees charged for the advice given

O Other (Please state) 


\section{APPENDIX 5: DIMENSIONS OF EMOTIONS EVOKED (BASED ON RICHINS (1997) CONSUMPTIONS SET (CES))}

Please indicate to what extent you feel the following emotions when considering your relationship with your main firm of solicitors [Seven point Likert scale: 1= "Not at all" and $7=$ "Extremely"]

Frustration; Optimism; Calmness, Astonishment, Worry, Enthusiasm, Sadness, Relief, Fear, Pleasure, Contentment, Shame, Discontentment, Pride

\section{APPENDIX 6: IMPORTANCE ATTACHED TO THE COMPONENTS OF SERVICE DELIVERY}

How important do you consider the following criteria when assessing the quality of service you receive from your main firm of solicitors?: [Seven point Likert scale: 1= "Not at all important" and 7= "Extremely Important"]

- The quality of the legal advice (e.g. The legal knowledge of the solicitor, its commercial applicability etc)

- How you interact with the solicitor (e.g. courtesy, empathy, reassurance etc)

- How responsive the solicitor is in terms of your requests (e.g. promptness. accessibility etc)

- How well you get on with the solicitor on a personal level

- The fees charged for the advice given

\section{APPENDIX 7: RESPONDENTS SELF ASSESSMENT OF THEIR KNOWLEDGE OF LAW AND LEGAL SERVICES (BASED ON MITCHELL AND DACIN'S (1996) ASSESSMENT OF CONSUMER EXPERTISE CRITERIA SCALE)}

\section{Please answer the following questions and statements}

- How familiar are you with the law and legal services in general? [Seven point Likert scale: 1= "Very unfamiliar" and 7= "Very familiar"]

- How confident are you about which elements of a legal service are most important? [Seven point Likert scale: $1=$ "Very unconfident" and 7= "Very confident"]

- How would you classify your legal knowledge relative to other people in general? [Seven point Likert scale: $1=$ "Well below average" and 7= "Well above average"]

- I know a lot about the law and legal services compared to other people in general ?[Seven point Likert scale: $1=$ "Strongly disagree" and 7= "Strongly agree"] 


\section{APPENDIX 8: PILOT PARTICIPANTS BY POSITION AND \\ ORGANISATIONAL TYPE}

\begin{tabular}{|l|l|}
\hline \multicolumn{1}{|c|}{ Position } & \multicolumn{1}{c|}{ Organisational type } \\
\hline Management consultant & Freelance \\
\hline Senior Chemist & Pharmaceutical Company \\
\hline Financial advisor & SME \\
\hline In-house lawyer & Local government \\
\hline Director of estates & University \\
\hline Associate solicitor & National law firm \\
\hline Associate solicitor & Regional law firm \\
\hline Company secretary & SME \\
\hline Academic & University \\
\hline Academic & University \\
\hline
\end{tabular}




\begin{tabular}{|l|c|c|}
\hline \multicolumn{1}{|c|}{ Items } & \multicolumn{1}{|c|}{$\begin{array}{c}\text { Factor 1: } \\
\text { Negative } \\
\text { Affect }\end{array}$} & $\begin{array}{c}\text { Factor 2: } \\
\text { Positive } \\
\text { Affect }\end{array}$ \\
\hline Sadness & .836 & \\
\hline Shame & .801 & \\
\hline Astonishment & .763 & \\
\hline Fear & .761 & \\
\hline Worry & .743 & \\
\hline Discontentment & .702 & \\
\hline Frustration & .566 & \\
\hline Contentment & & .804 \\
\hline Enthusiasm & & .803 \\
\hline Pleasure & & .800 \\
\hline Pride & & .786 \\
\hline Optimism & & .670 \\
\hline Calmness & & .590 \\
\hline
\end{tabular}

Table I: Factor analysis results: Affective component

\begin{tabular}{|l|c|c|c|}
\hline \multicolumn{1}{|c|}{ Item } & $\begin{array}{c}\text { Factor 1: } \\
\text { Technical } \\
\text { Element }\end{array}$ & $\begin{array}{c}\text { Factor 2: } \\
\text { Interaction } \\
\text { Element }\end{array}$ & $\begin{array}{c}\text { Factor 3: } \\
\text { Responsiveness } \\
\text { Element }\end{array}$ \\
\hline Legal specialisation & .741 & & \\
\hline Commercial viability & .728 & & \\
\hline Quality of legal advice & .717 & & \\
\hline Reliability & .690 & & \\
\hline Legal detail & .645 & & \\
\hline Clarity & .636 & .728 & \\
\hline How well you get on & & .680 & \\
\hline Empathy & & .642 & \\
\hline Cultural fit & & .632 & .823 \\
\hline Courtesy & & & .800 \\
\hline Accessibility & & & \\
\hline Promptness & & & \\
\hline
\end{tabular}

Table II: Factor analysis results: Cognitive components of service 
SME Respondents

\begin{tabular}{|c|c|c|c|c|c|c|}
\hline $\begin{array}{c}\text { Dependent } \\
\text { Variable }\end{array}$ & $\begin{array}{c}\text { Independent } \\
\text { Variable }\end{array}$ & $\begin{array}{c}\text { Standardized } \\
\text { Coefficients } \\
(\beta)\end{array}$ & $\begin{array}{c}\text { t- } \\
\text { value }\end{array}$ & VIF & Sig & Model R2 \\
\hline Overall & (Constant) & .332 & 3.896 & 1.934 & .000 & .621 \\
Satisfaction & RESPCOMP & .304 & 3.259 & 2.319 & .002 & \\
& INTECOMP & .198 & 2.750 & 1.388 & .007 & \\
& POSAFFE & -.246 & -3.880 & 1.070 & .000 & \\
& NEGAFFE & -38 & & & \\
& & & &
\end{tabular}

Table III: Regression Analysis with POSAFFE (Positive Affect), NEGAFFE (Negative Affect), INTECOMP (Interaction Component) and RESPCOMP (Responsiveness Component), TECHCOMP

(Technical Component) and FEES (Fees)

In-house Lawyers

\begin{tabular}{|c|c|c|c|c|c|c|}
\hline $\begin{array}{c}\text { Dependent } \\
\text { Variable } \\
\text { (Transformed) }\end{array}$ & $\begin{array}{l}\text { Independent } \\
\text { Variables } \\
\text { (Transformed) }\end{array}$ & $\begin{array}{c}\text { Standardized } \\
\text { Coefficients } \\
(\beta)\end{array}$ & $\begin{array}{c}\mathrm{t}- \\
\text { value }\end{array}$ & VIF & Sig & Model $R 2$ \\
\hline $\begin{array}{c}\text { Overall } \\
\text { Satisfaction }\end{array}$ & $\begin{array}{c}\text { (Constant) } \\
\text { RESPCOMP } \\
\text { INTECOMP } \\
\text { TECHCOMP } \\
\text { POSAFFE } \\
\text { FEES }\end{array}$ & $\begin{array}{l}.170 \\
.202 \\
.259 \\
.142 \\
.231\end{array}$ & $\begin{array}{l}-6.720 \\
2.551 \\
2.459 \\
2.969 \\
2.439 \\
3.561\end{array}$ & $\begin{array}{l}1.965 \\
2.969 \\
3.351 \\
1.482 \\
1.856\end{array}$ & $\begin{array}{l}.000 \\
.012 \\
.015 \\
.003 \\
.016 \\
.001\end{array}$ & .661 \\
\hline
\end{tabular}

Table IV: Regression Analysis with POSAFFE (Positive Affect), NEGAFFE (Negative Affect), INTECOMP (Interaction Component) and RESPCOMP (Responsiveness Component), TECHCOMP (Technical Component) and FEES (Fees) 